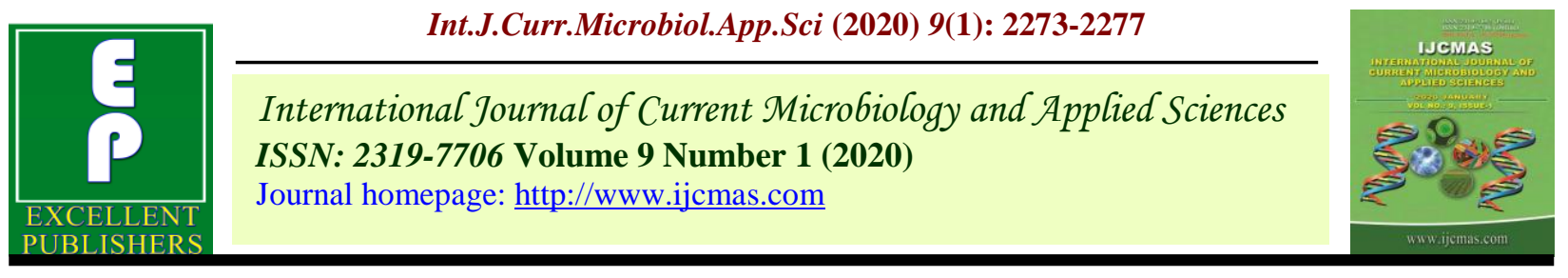

Original Research Article

https://doi.org/10.20546/ijcmas.2020.901.258

\title{
Profile of Extension Personnel Working in State Agriculture Department of Marathwada Region, India
}

\author{
Amita M. Kshatriya*, P. R. Deshmukh and N. D. Kale \\ Department of Extension Education, VNMKV, Parbhani. (M.S.), India \\ *Corresponding author
}

\begin{tabular}{|l|}
\hline Key w or d s \\
Extension \\
personnel, One third \\
proportionate \\
random sampling, \\
Workload
\end{tabular}

\section{A B S T R A C T}

The present study was conducted in Parbhani and Nanded district of Marathwada region in Maharashtra state. Out of eight district of Marathwada, Nanded \&Parbhani district were selected randomly for the study. The all 25 taluka from Nanded \& Parbhani district was selected randomly for the present study. Thus of 236 extension personnel from Parbhani \& Nanded district were selected by One third $(1 / 3)$ of proportionate random sampling method. The data were collected with the help of presented interview from respondents at their office. Ex-post facto research design was adopted in this study. The data were collected with the help of pretested interview schedule from the respondents as per their convenience at their home or farms. The study had shown the results as under, that extension personnel were belongs from middle age group, Most of the extension personnel were male, qualification up to agri.diploma/GTC level, most of them were belongs from medium service experience, More than half of them having medium perceived workload, Most of them were belongs to medium achievement motivation, Majority of them having high competition orientation. More than half of the extension personnel had favourable attitude towards organization. Majority of them having high training undergone, More than half of the extension personnel had medium organization climate, more than half of them had medium level of work environment, greater number of extension personnel were having medium level of mass media exposure.

\section{Introduction}

Agriculture department considers farmer as the focal point and the whole department is organized in such a fashion that a single mechanism is working to facilitate the farmer for adoption of advanced technology and sustainable use of available resources. The extension personnel i.e. Agriculture Assistant at village level undertakes soil conservation work, horticulture plantation and various extension schemes. He is supervised by Circle Agriculture Officer at circle level. Administrative control, laison with other departments, monitoring and training programs etc. are facilitated by Taluka Agriculture Officer at taluka level, Sub Divisional Agriculture Officer at sub division 
level, District Superintending Agriculture Officer at district level and Divisional Joint Director at division level. In addition, Agriculture Officer at Panchayat Samiti level, working under Agriculture Development Officer, Zilla Parishad at district level also implements various agro-inputs related schemes.

All the schemes implemented in the field are supervised technically and administratively by respective directorates of Soil Conservation, Horticulture, Extension and Training, Inputs and Quality Control, Statistics, Monitoring and Evaluation and Planning and Budget at state level in the Commissionerate of Agriculture. Also separate sections are there for the Establishment and Accounts related matters. To study the profile of the extension personnel will help to understand the job perception, job performance, job satisfaction and job stress of extension personnel working in state agriculture department.

\section{Materials and Methods}

The present study was conducted in Parbhani and Nanded district of Marathwada region in Maharashtra state. Out of eight district of Marathwada, Nanded \&Parbhani district were selected randomly for the study. The all 25 taluka from Nanded \& Parbhani district was selected randomly for the present study Thus of 236 extension personnel from Parbhani \& Nanded district were selected by One third
(1/3) of proportionate random sampling method i.e. The description of respondents is out of 24 Taluka agriculture officer only 8 , out of 31 Circle Agriculture Officer only 10 out of 107 Agriculture supervisor only 36 and out of 545 Agriculture Assistants only 182 was selected from total 708 Extension Personnel working in state Agriculture Department.

Ex-post facto research design was adopted in this study. The data were collected with the help of pretested interview schedule. The statistical methods and tests such as frequency, percentage, mean, standard deviation, co-efficient of correlation, multiple regressions and path analysis were used for the analysis of data.

\section{Results and Discussion}

\section{Profile of extension personnel working in state agriculture department}

The present study was to study the profile of extension personnel working in state agriculture department of Marathwada region i.e. age, gender, qualification, service experience, perceived workload, achievement motivation competition orientation, attitude towards organization, training undergone, work environment and mass media exposure. Data were analyzed in respect to above listed variables and the results are presented here under.

Table.1

\begin{tabular}{|r|c|c|c|c|}
\hline $\begin{array}{r}\text { Sr. } \\
\text { No }\end{array}$ & Characteristics & Category & Frequency & Percentage \\
\hline & & Young & 47 & 19.92 \\
\hline $\mathbf{1 .}$ & Age & Middle & 143 & 60.59 \\
\hline & & Old & 46 & 19.49 \\
\hline & & & Mean $=\mathbf{4 1 . 0 0}$ S.D $=\mathbf{8 . 0 0}$ \\
\hline $\mathbf{2 .}$ & Gender & Male & 195 & 82.63 \\
\hline & & Female & 41 & 17.37 \\
\hline
\end{tabular}




\begin{tabular}{|c|c|c|c|c|}
\hline & & $\begin{array}{l}\text { Agri. Diploma } \\
\text { /GTC }\end{array}$ & 103 & 43.64 \\
\hline & & B.Sc (Agri/Horti) & 79 & 33.47 \\
\hline \multirow[t]{4}{*}{3.} & Qualification & M.Sc (Agri/Horti) & 53 & 22.46 \\
\hline & & Ph.D Specialization & 1 & 0.43 \\
\hline & & Low & 42 & 17.79 \\
\hline & Service & Medium & 149 & 63.13 \\
\hline \multirow[t]{3}{*}{4.} & Experience & High & 45 & 19.06 \\
\hline & (years) & & Mean $=16.00$ & S.D. $=9.00$ \\
\hline & & Low & 68 & 28.81 \\
\hline \multirow[t]{5}{*}{5.} & Perceived & Medium & 123 & 52.12 \\
\hline & workload & High & 45 & 19.07 \\
\hline & & & Mean $=15.00$ & S.D $=3.00$ \\
\hline & & Low & 49 & 20.76 \\
\hline & Achievement & Medium & 140 & 59.32 \\
\hline \multirow[t]{3}{*}{6.} & Motivation & High & 47 & 19.92 \\
\hline & & & Mean $=24.00$ & S.D. $=\mathbf{3 . 0 0}$ \\
\hline & & Low & 53 & 22.46 \\
\hline \multirow[t]{4}{*}{7.} & Competition & Medium & 83 & 35.17 \\
\hline & Orientation & High & 100 & 42.37 \\
\hline & & & Mean $=4.00$ & S.D. $=1.00$ \\
\hline & & Unfavorable & 78 & 33.05 \\
\hline \multirow[t]{3}{*}{8.} & Attitude & Favorable & 121 & 51.27 \\
\hline & towards & More Favorable & 37 & 15.68 \\
\hline & organization & & Mean=33.00 & S.D. $=4.00$ \\
\hline \multirow[t]{4}{*}{9.} & & Low & 29 & 12.29 \\
\hline & Training & Medium & 91 & 38.56 \\
\hline & undergone & High & 116 & 49.15 \\
\hline & & Low & 71 & 30.08 \\
\hline \multirow[t]{4}{*}{10.} & Organization & Medium & 132 & 55.93 \\
\hline & climate & High & 33 & 13.98 \\
\hline & & & Mean $=29.00$ & S.D. $=3.00$ \\
\hline & & Low & 82 & 34.75 \\
\hline \multirow[t]{3}{*}{11.} & Work & Medium & 123 & 52.12 \\
\hline & Environment & High & 31 & 13.14 \\
\hline & & Low & 49 & 20.76 \\
\hline \multirow[t]{3}{*}{12.} & Mass Media & Medium & 139 & 58.90 \\
\hline & Exposure & High & 48 & 20.34 \\
\hline & & & Mean $=6.00$ & S.D. $=\mathbf{2 . 0 0}$ \\
\hline
\end{tabular}


Summary and conclusion of the study are as follows:

It was noticed that majority of the extension personnel were belongs from middle age group.(60.59\%), Most of the extension personnel were male $(82.63 \%)$, qualification up to agri. diploma/GTC level 43.64 .00 per cent, most of them $(63.13 \%)$ were belongs from medium service experience, More than half of them having medium perceived workload 52.12 per cent, Most of them were belongs to medium achievement motivation (59.32\%), Majority of them having high competition orientation 42.37 per cent. More than half $(51.27 \%)$ of the extension personnel had favorable attitude towards organization.

Majority (49.15\%) of them having high training undergone, More than half (55.93\%) of the extension personnel had medium organization climate, more than half of them had medium level of work environment (52.12\%), greater number of extension personnel were having medium level of mass media exposure $(58.90 \%)$.

\section{Implications}

It was found that majority of extension personnel were having medium perceived workload, achievement motivation, organization climate, work environment and mass media exposure. Therefore, it is implied that the work should be given to employee according to their capability or resources \& amount required by the task, promotion and rewards could be done for good work, flexible work schedules and good working climate must be provided to the employees, this will motivate and increase the morale of extension personnel.

\section{References}

Ajayai, Isaac A, A Wosusi, Omojola O, Arogundade, Bukola B and Eundayo, Haastrup T. (2011). Work environment as correlate of academic staff job performance in south west Nigeria Universties.

Ali Yassin Sheikh Ali, Dahie Abdulkadir Mohamud, Ali Abdulkadir Ali. (2016). Teacher motivation and school performance, the mediating effect of job satisfaction: survey from secondary schools in Mogadishu. International Journal of Education and Social Science. www.ijessnet.com Vol. 3 No. 1; January 2016.

Asmui M., Hussin, A. and Paino H. (2012). The importance of work environmental facilities. International Journal of Learning and Development, 2 (1): 8997.

Fazely, A.S. (2016). (Agri), Thesis A Study on job perception, job performance and job satisfaction of teachers of state Agricultural Universities in Karnataka

Jini, V. (2006). A comparative analysis of organizational climate and time management of Agricultural Faculty in two State Agricultural Universities of South India, M.Sc. (Agri.), Thesis (Unpub.), University of Agricultural Sciences, Bangalore. 886 .

Kiran, T. R. (2007). Perception of Organizational Climate by Scientists of University of Agricultural Sciences, Dharwad, M. Sc. (Agri.) Thesis, University of Agricultural Sciences Dharwad.

Nurharani, S., Nur, Z. S. and Nur, S. M. K. (2013). The impact of organizational climate on teachers' job performance. $e$ Journal Edu. Res., 2(1): 71-82. 


\section{How to cite this article:}

Amita M. Kshatriya, P. R. Deshmukh and Kale, N. D. 2020. Profile of Extension Personnel Working in State Agriculture Department of Marathwada Region, India. Int.J.Curr.Microbiol.App.Sci. 9(01): 2273-2277. doi: https://doi.org/10.20546/ijcmas.2020.901.258 